Studia nad Autorytaryzmem i Totalitaryzmem 43, nr 4 Wrocław 2021

https://doi.org/10.19195/2300-7249.43.4.6

\author{
KATARZYNA GÓRSKA \\ ORCID: 0000-0002-3773-3617 \\ Uniwersytet Wrocławski, \\ katarzyna.gorska@uwr.edu.pl
}

\title{
Stosowanie przepisów o formie czynności prawnych jako instrument kontroli obrotu prawnego w perspektywie orzecznictwa SN w latach 1964-1989
}

Słowa kluczowe: swoboda formy czynności prawnych, forma szczególna, kodeks cywilny, dokumentacja obrotu, orzecznictwo Sądu Najwyższego, kontrola obrotu.

\author{
APPLICATION OF REGULATIONS ON THE FORM OF LEGAL ACTIONS \\ AS AN INSTRUMENT OF CONTROLLING LEGAL TRANSACTIONS \\ IN THE CONTEXT OF SUPREME COURT JURISPRUDENCE IN THE YEARS 1964-1989
}

\begin{abstract}
The regulation of civil law transactions during the Polish People's Republic took place on many different levels. Among other things, the scope of state control over the performance of legal transactions also involved the obligation to document them. At the normative level, the code institution of the form of legal transactions reflected classical civilist concepts, typical for free-market relations. The aim of the study is to determine to what extent the principle of freedom of form expressed in the Civil Code was respected in practice, and to what extent the application of the rules on form made them another tool at the disposal of the totalitarian state to control transactions. Judicial jurisprudence seems to be the most appropriate area to analyze this problem. The article presents selected theses of the Supreme Court relating to the application of regulations on the form of legal transactions, formulated in the years 1964-1989, that is, from the enactment of the Civil Code to the beginning of the political and economic transformation towards democracy and free-market economy. The main considerations are preceded by a presentation of the code regulation of the form of legal actions with an indication of the basic functions, which - in the intention of the authors of the Civil Code - were ascribed to the form of legal actions. The part of the study devoted to the discussion of the jurisprudence explains, first of all, how the principle of the freedom of form was understood and how the provisions on the special form and the consequences of failing to observe it were applied. The conclusions that emerge from the analysis do not allow us to formulate a thesis about an ideological interpretation by the Supreme Court. In particular, it cannot be confirmed that the use of provisions on form testified to their instrumentalization. This leads us to reflect that the political
\end{abstract}


conditions of the communist period did not preclude the Supreme Court from interpreting the law in a fully autonomous manner. For this reason, much of the case law from that period is still relevant.

Keywords: freedom of form of legal transactions, specific form, Civil Code, legal trade documentation, Supreme Court rulings, trade control.

\section{Wprowadzenie}

Po II wojnie światowej kolejne działania prawotwórcze nowej władzy ludowej systematycznie marginalizowały znaczenie majątkowego prawa cywilnego ${ }^{1}$. Sytuacji nie zmieniło ostateczne doprowadzenie do przyjęcia w 1964 roku kodeksu cywilnego $^{2}$. Regulacja kodeksowa, mimo iż pod wieloma względami stanowiła wyraz kontynuacji klasycznej myśli cywilistycznej, została w istotnym stopniu nasycona elementami ideologicznymi, które wynikały z przyjętych zasad mających stanowić podstawę nowego systemu gospodarczego. Wyrazem tego był art. 4 k.c., w którym to artykule jednoznacznie ustalono, że ,przepisy prawa cywilnego powinny być thumaczone i stosowane zgodnie z zasadami ustroju i celami Polskiej Rzeczypospolitej Ludowej”. Zarówno zasady te, jak i cele były zaś jednoznaczne. Przewidywały one wprowadzenie centralnego planowania gospodarczego zastępującego mechanizmy wolnorynkowe oraz typologię własności z wyraźnym uprzywilejowaniem własności społecznej (w tym zwłaszcza jednolitej własności państwowej) przy jednoczesnym stopniowym marginalizowaniu własności prywatnej ${ }^{3}$. Równolegle praktyczny zakres zastosowania kodeksu kurczył się między innymi w związku z przewidzianą w art. 2 k.c. klauzulą derogacyjną umożliwiającą organom państwowym wprowadzanie, odrębnych od kodeksowych, unormowań odnoszących się do stosunków między jednostkami gospodarki uspołecznionej, a także w związku z innymi przepisami kodeksu bądź to odsyłającymi do aktów wykonawczych, bądź udzielającymi kompetencji do uregulowania określonej materii przez organy państwowe $\mathrm{e}^{4} \mathrm{~W}$ ten sposób obszar należący dotąd do prawa prywatnego stawał się domeną prawa publicznego i wynikającej z niego rozbudowanej regulacji administracyjnej i fiskalnej.

1 Zjawisko to opisuje szerzej Z. Radwański, Prawo cywilne PRL, „Czasopismo Prawno-Historyczne" 1995, z. 1-2, s. 23-26.

2 Ustawa z dnia 23 kwietnia 1964 roku — Kodeks cywilny (Dz.U. z 1964 r. Nr 16, poz. 93), weszła w życie w dniu 1 stycznia 1965 roku.

${ }^{3}$ Zob. Z. Radwański, op. cit., s. 26. Realizowały one założenia wynikające z marksistowsko-leninowskiej doktryny leżącej u podstaw ustroju socjalistycznego, zakładające między innymi zmianę granic między sferą prawa prywatnego a sferą prawa publicznego, odejście od zasady formalnej równości wobec prawa oraz abstrakcyjnego pojęcia własności i autonomii woli stron (zob. A. Machnikowska, Wplyw ustawodawstwa stanu wojennego na prawo cywilne w Polsce, ,Studia nad Autorytaryzmem i Totalitaryzmem" 39, 2017, nr 3, s. 23).

4 Jak na przykład w art. 384 k.c. $\$ 1$ k.c., na podstawie którego Rada Ministrów lub z jej upoważnienia inny naczelny organ administracji państwowej mogły ustalać ogólne warunki lub wzory umów dla określonej kategorii umów między jednostkami gospodarki uspołecznionej albo między tymi jednostkami a innymi osobami. 
W tych okolicznościach należy się zgodzić z opinią, że kodeks cywilny miał mniejsze znaczenie, niż chciano mu przypisywać ${ }^{2}$. Choćby tylko w zakresie kluczowej dla prawa prywatnego zasady autonomii woli podmiotów doszło do jej znacznego ograniczenia wskutek realizacji założeń gospodarki nakazowo-rozdzielczej. Jednocześnie kodeks cywilny nie był aktem bez znaczenia. O tym, w jaki sposób elementy ideologiczne determinowały obrót cywilnoprawny, przesądzało bowiem nie tylko to, jaki był stan istniejącego prawodawstwa, lecz także to, w jaki sposób przepisy te były interpretowane. $\mathrm{W}$ tym zaś zakresie istotną rolę odgrywało orzecznictwo sądowe.

Przedmiotem analizy tego opracowania uczyniono, widzianą z perspektywy orzeczniczej, problematykę formy czynności prawnych. Przedstawione rozważania biorą pod uwagę powyższy kontekst i koncentrują się na wybranym zagadnieniu.

Na poziomie normatywnym instytucja formy nie została poddana szczególnej ideologizacji. Przeciwnie, kodeks cywilny śladem rozwiązań przyjętych w dotychczasowej regulacji prawnej wyrażał zasadę swobody formy. Można by więc przyjąć, że reglamentacja obrotu wynikająca z założeń gospodarki nakazowo-rozdzielczej nie wyłączyła możliwości swobodnego, co do zasady, składania oświadczeń woli. Zakres działania tej zasady był jednak — rzecz jasna — uwarunkowany wieloma czynnikami. Warto podkreślić, że bez względu na panujący ustrój polityczny i związany z nim model gospodarczy do takich czynników należą zarówno ograniczenia stricte ustawowe ${ }^{6}$, jak $\mathrm{i}$ te wynikające $\mathrm{z}$ sądowej praktyki stosowania prawa.

Przegląd orzecznictwa sądowego dotyczącego formy czynności prawnych pozwoli określić, na ile ustrojowy totalitaryzm okresu PRL znajdował odzwierciedlenie w obszarze gospodarczym w postaci wzmocnionej kontroli dokumentowania obrotu cywilnoprawnego ${ }^{7}$. W pewnym sensie określi również i to, czy i ewentualnie w jakim stopniu SN stał się w analizowanym obszarze wyrazicielem ideologii socjalistycznego państwa.

Dokonanie analizy w tym względzie warto poprzedzić uwagą, iż stosowanie przepisów o formie, widziane z perspektywy wykorzystania tej instytucji jako instrumentu kontroli obrotu, mogło wyrażać się w zróżnicowany sposób i znajdować wyraz zarówno w zaostrzaniu wymogów formalnych (na przykład przez dążenie do maksymalizacji katalogu czynności prawnych wymagających zachowania formy szczególnej lub włączanie organów administracji publicznej w proces dokonywania czynności prawnych), jak i w ich łagodzeniu (na przykład przez osłabianie rygoru niedochowania formy w celu ustalenia faktu i treści dokonywanych czynności).

5 Tak A. Machnikowska, op. cit., s. 27.

${ }^{6}$ Mam w tym wypadku na myśli takie ograniczenia jak wynikające z mocy ustawy obowiązki zachowania formy szczególnej dla dokonania określonej czynności prawnej czy stopień skomplikowania przesłanek warunkujących dochowanie formy szczególnej.

7 Przedmiotem analizy objęte zostaną wybrane orzeczenia Sądu Najwyższego (dalej: SN) w latach 1964-1989, to jest od czasu uchwalenia kodeksu cywilnego do 1989 roku, wyznaczającego początek transformacji politycznej i gospodarczej w kierunku demokracji i gospodarki rynkowej. 
Wskazanie wybranych wątków judykatury oraz ich zbadanie pod kątem wpływu orzecznictwa na stosowanie przepisów o formie wymaga, dla uporządkowania rozważań, zwięzłego przedstawienia samej regulacji prawnej.

\section{Podstawowe założenia kodeksowej regulacji o formie czynności prawnych}

Regulacja formy czynności prawnych w uchwalonym w 1964 roku kodeksie cywilnym stanowiła zasadniczo odzwierciedlenie konstrukcji przyjętych we wcześniej obowiązujących przepisach, w tym również wyraźnie nawiązujących do przedwojennego kodeksu zobowiązań ${ }^{8}$. Przepisy o formie przyjęte w pierwotnej wersji kodeksu cywilnego przetrwały w tym kształcie bez większych zmian 38 lat ${ }^{9}$.

W art. 60 k.c. (wzorem art. 29 k.z. oraz art. 43 p.o.p.c. z 1950 roku) podtrzymano zasadę swobody formy. Ponadto, w księdze I k.c. w dziale III tytułu IV poświęconego czynnościom prawnym zawarto uregulowanie, w którego ramach dało się wyróżnić trzy podstawowe grupy przepisów dotyczących formy. Należały do nich przepisy: określające skutki niedochowania formy szczególnej (art. 73-74 k.c. i art. 76 k.c.), określające przesłanki zachowania wskazanych typów formy szczególnej (art. 78-81 k.c.) oraz określające wymogi zachowania formy szczególnej dla wskazanych czynności prawnych (art. 75 i 77 k.c.).

8 Po II wojnie światowej przepisy należące do części ogólnej prawa cywilnego, w tym przepisy o formie, były przedmiotem kilku aktów prawnych. W art. 10 dekretu z dnia 12 listopada 1946 roku - Przepisy ogólne prawa cywilnego (Dz.U. z 1946 r. Nr 67, poz. 369) wyrażono zasadę kontynuacji w stosunku do regulacji formy zawartej w kodeksie zobowiązań (Rozporządzenie Prezydenta RP z 27 października 1933 roku — Kodeks zobowiązań, Dz.U. z 1933 r. Nr 82, poz. 598), jednocześnie nakazując odpowiednie stosowanie tych przepisów do oświadczeń woli przewidzianych $\mathrm{w}$ innych przepisach prawa cywilnego. Pierwsza istotna zmiana w tak ustalonym stanie prawnym nastąpiła niespełna pięć lat później. Zgodnie z ustawą z dnia 18 lipca 1950 roku Przepisy wprowadzające przepisy ogólne prawa cywilnego (Dz.U. z 1950 r. Nr 34, poz. 312; dalej: p.o.p.c.) dekret z 1946 roku stracił moc (art. I ustawy) a także zniesiono przepisy prawa cywilnego przewidujące pisemną formę oświadczeń woli dla celów dowodowych (art. II ustawy). W nowych przepisach ogólnych prawa cywilnego (przyjętych ustawą z dnia 18 lipca 1950 roku, Dz.U. z 1950 r. $\mathrm{Nr} 34$, poz. 311) utrzymano jednak wyrażoną w art. 29 kodeksu zobowiązań zasadę swobody formy. Wynikające z ustawy odstępstwo od tej zasady mogło mieć postać formy zastrzeżonej pod rygorem nieważności - co traktowano jako zasadę - lub dla wywołania szczególnych skutków prawnych (art. 63 p.o.p.c). Dodatkowo w ustawie tej uregulowano przesłanki zachowania formy pisemnej (art. 65 p.o.p.c.) wraz z zastępczymi postaciami tej formy przewidzianymi dla osób nieumiejących lub niemogących pisać, lecz mogących czytać (art. 66 p.o.p.c.) oraz osób nieumiejących lub niemogących czytać (art. 67 p.o.p.c.). Wprowadzono również regulację związaną z tak zwaną datą pewną (art. 68 p.o.p.c.).

9 Pierwsza istotniejsza nowelizacja w tym względzie została dokonana ustawą z dnia 14 lutego 2003 roku o zmianie ustawy — Kodeks cywilny oraz niektórych innych ustaw (Dz.U. z 2003 r. $\mathrm{Nr} 49$, poz. 408). 
Według założeń kodeksowych ustawodawca przewidział w przepisach art. 73 i 74 k.c. trzy możliwe skutki niezachowania formy szczególnej, a mianowicie: bezwzględną nieważność czynności prawnej (forma ad solemnitatem — art. $73 \S 1 \S 2$ zd. 1 k.c.), niedopuszczalność dowodu z zeznan świadków lub z przesłuchania stron (forma ad probationem — art. $74 \S 1$ k.c.) oraz niewywołanie przez czynność prawną określonych skutków prawnych (forma ad eventum — art. 73 § zd. 2 k.c., art. 74 $\S 1$ zd. 2 k.c.). Zdecydowano zatem o przywróceniu, zniesionej w 1950 roku, formy dla celów dowodowych ${ }^{10}$. Zgodnie $\mathrm{z}$ art. 74 k.c. w takim charakterze mogła jednak zostać zastrzeżona wyłącznie zwykła forma pisemna. Tego ograniczenia nie przewidziano w odniesieniu do ,innych form szczególnych”, wobec czego każda forma (zarówna zwykła pisemna, jak i jakakolwiek inna) mogła występować w obrocie $\mathrm{w}$ postaci formy ad solemnitatem albo ad eventum. Reguły dotyczące potencjalnych sankcji związanych z niezachowaniem wymogu zostały zaprojektowane jako uniwersalne w tym sensie, że znajdowały zastosowanie w każdym przypadku, gdy z ustawy lub czynności prawnej wynikał wymóg zachowania formy szczególnej.

Gdy chodzi o zawarte w dziale III tytułu IV księgi I k.c. przepisy określające przesłanki zachowania formy szczególnej, to - śladem poprzednich unormowań - nie przewidziano bardziej kompleksowej regulacji, w postaci wskazania choćby przykładowego katalogu form szczególnych. Ustawodawca wspominał jedynie o „formie pisemnej” oraz o ,innych formach szczególnych”. W ten sposób ustalenie katalogu form szczególnych pozostawiono doktrynie, która musiała w tej kwestii posiłkować się typami form dającymi się wyodrębnić na podstawie całokształtu regulacji prawnej. W ramach części ogólnej uregulowana została jedynie forma pisemna (art. 78 k.c.), jej zastępcze postaci (art. 79-80 k.c.) oraz urzędowe poświadczenie daty (art. 81 k.c.), które stało się podstawą wyróżniania w nauce tak zwanej formy $\mathrm{z}$ datą pewną. Z kolei w księdze IV k.c. uregulowane zostały formy testamentów zwykłych (art. 949-951 k.c.) oraz testamentów szczególnych (art. 952-954 k.c.). Poza materią kodeksową znalazła się forma aktu notarialnego ${ }^{11}$.

W ramach przepisów ustanawiających wymóg zachowania formy szczególnej przewidziano dwa, mające ogólny zakres zastosowania, przepisy prawa. I tak w art. 77 k.c. uregulowano formę czynności następczych. Z kolei w związku ze

${ }^{10}$ Losy formy dla celów dowodowych były w polskim ustawodawstwie dość zmienne, sama zaś instytucja budziła kontrowersje (na ten temat szerzej zob. między innymi A. Szpunar, Uwagi o formie przewidzianej dla celów dowodowych, „Ruch Prawniczy, Ekonomiczny i Socjologiczny” 1987, z. 4; K. Górska, O perspektywie zniesienia formy pisemnej dla celów dowodowych, „Rejent” 2008, $\mathrm{nr}$ 12; M. Grochowski, Forma oświadczenia woli dla celów dowodowych — enfant terrible polskiej cywilistyki, [w:] Profesor Aleksander Wolter - w 105. rocznice urodzin, red. M. Grochowski, Lublin 2010). O wyeliminowaniu formy ad probationem w 1950 roku przesądziło zdanie, że jej zastosowanie kłóci się z podstawową dla procesu socjalistycznego zasadą prawdy obiektywnej. Zniesienie formy ad probationem nie było jednak całkowite, ponieważ nie dotyczyło praktyki arbitrażowej.

$11 \mathrm{Na}$ dzień uchwalenia kodeksu cywilnego forma aktu notarialnego była regulowana w art. 45 ustawy z dnia 25 maja 1951 roku — Prawo o notariacie, to jest z dnia 8 kwietnia 1963 roku (Dz.U. z 1963 r. Nr 19, poz. 106). Także po transformacji ustrojowej w 1989 roku nie zdecydowano się na włączenie tej formy do regulacji kodeksowej. 
wskrzeszeniem formy dla celów dowodowych ustanowiono obowiązek stwierdzenia pismem czynności zobowiązujących lub rozporządzających, których wartość świadczenia przenosiła kwotę 10 tysięcy złotych ${ }^{12}$. Poza tym obowiązek zachowania formy wynikał z szeregu przepisów szczególnych (w tym również pozakodeksowych), odnoszących się do konkretnych czynności prawnych ${ }^{13}$.

Zastosowanie przedstawionych przepisów o formie odnosiło się do wszystkich stosunków objętych kodeksem cywilnym, w tym również stosunków handlowych i stosunków między jednostkami gospodarki uspołecznionej ${ }^{14}$. Należy jednak wspomnieć, że na podstawie art. VI $§ 2$ przepisów wprowadzających k.c. ${ }^{15}$ stosowanie formy dla celów dowodowych zostało wyłączone w stosunkach handlu zagranicznego. Z kolei ze względu na, wynikające z założeń realnego socjalizmu, uznanie prawa pracy za odrębny dział prawa, przepisy o formie nie znalazły bezpośredniego zastosowania do stosunków prawa pracy ${ }^{16}$.

$\mathrm{Na}$ koniec tego fragmentu rozważań trzeba zaznaczyć, że gdy chodzi o funkcje formy realizowane w przyjętym modelu kodeksowym, to dostrzegano w tym względzie pełną analogię do typowych funkcji formy wyznaczanych w nowożytnych systemach prawa. Realizacja przepisów o formie miała zatem służyć przede wszystkim:

(1) uchyleniu wątpliwości, czy oświadczenie woli zostało złożone [...]; (2) ułatwieniom dowodowym; (3) ochronie samych stron przed nieprzemyślanymi decyzjami; (4) jawności czynności prawnej w stosunku do osób trzecich; (5) ułatwieniu sprawowania kontroli państwa nad dokonywaniem czynności prawnych ${ }^{17}$.

12 Wymóg ten był nowością na gruncie polskiego prawa cywilnego. Kodeks zobowiązań nie wprowadzał ogólnego obowiązku zachowania formy szczególnej ze względu na wartość dokonywanej czynności prawnej, a przepisy dawnego prawa przewidywały formę ad probationem w powiązaniu z wartością czynności prawnej jedynie w szczególnych sytuacjach, na przykład umowy pożyczki (zob. na ten temat A. Szpunar, op. cit., s. 53).

13 Trafnie dostrzegano w doktrynie, że ocena modelu przepisów o formie powinna być dokonywana w kontekście całościowej oceny ustawowych przypadków, dla których ustawodawca przewidział obowiązek zachowania formy, z uwzględnieniem sankcji jej niedochowania. Wątek ten wykracza poza ramy tego opracowania — zob. na ten temat S. Grzybowski, [w:] System prawa cywilnego. t. 1. Część ogólna, Wrocław 1974, s. 566-568.

${ }^{14}$ Zakres podmiotowy kodeksu cywilnego był wyznaczony w art. 1. Zgodnie z tym artykułem obejmował on przede wszystkim stosunki cywilnoprawne między jednostkami gospodarki uspołecznionej, między osobami fizycznymi oraz między jednostkami gospodarki uspołecznionej a osobami fizycznymi $(\S 1)$. Ponadto przepisy kodeksu dotyczace jednostek gospodarki uspołecznionej należało stosować do ,instytucji państwowych i organizacji społecznych ludu pracującego, których zadanie nie polega na prowadzeniu działalności gospodarczej” (§2), a przepisy dotyczące osób fizycznych należało stosować - o ile z przepisów kodeksu lub innych ustaw nie wynikało nic innego - do osób prawnych nie będących jednostkami gospodarki uspołecznionej”.

15 Ustawa z dnia 23 kwietnia 1964 roku - Przepisy wprowadzające kodeks cywilny (Dz.U. z 1964 r. Nr 16, poz. 94).

16 Art. XII § 1 przepisów wprowadzających kodeks cywilny stanowił, że kodeks cywilny nie narusza przepisów ustawodawstwa pracy, a w $§ 3$ tego przepisu wskazano, że do stosunków pracy nie stosuje się art. 73-77 k.c., o ile dotyczą one formy pisemnej przewidzianej dla celów dowodowych.

17 Z. Radwański, [w:] System prawa cywilnego, t. 1. Część ogólna, red. S. Grzybowski, Wroclaw 1985, s. 622.

Studia nad Autorytaryzmem i Totalitaryzmem 43, nr 4, 2021

(C) for this edition by CNS 
Zwrócono przy tym uwagę, że w ustroju socjalistycznym większą doniosłość społeczną ma funkcja kontrolna ${ }^{18}$. Między innymi właśnie argumenty o możliwości uzyskania dodatkowego instrumentu kontroli nad obrotem uspołecznionym oraz zapewnienia większej dyscypliny społecznej przesądziły na etapie prac Komisji Kodyfikacyjnej o przywróceniu formy dla celów dowodowych ${ }^{19}$. Świadomość tej funkcji mogła mieć zatem wpływ na wykładnię przepisów dokonywaną w procesie stosowania prawa.

\section{Stanowisko judykatury - wybrane wątki}

\subsection{Swoboda formy}

Wyrażona w art. 60 k.c. zasada swobody formy czynności prawnej ma znaczenie dla tej części obrotu, która nie jest poddana ścisłej reglamentacji ustawowej. W okresie gospodarki centralnej wynikający z art. 4 k.c. wymóg, aby przepisy prawa thumaczyć i stosować zgodnie z zasadami ustroju PRL, stwarzał jednak możliwość, aby swoboda podmiotów w zakresie sposobu wyrażania swojej woli w stosunkach cywilnoprawnych była interpretowana przez pryzmat ideologicznej potrzeby kontrolowania obrotu. Analiza orzecznictwa w zakresie art. 60 k.c. nie pozwala jednak na wysunięcie takich wniosków. SN wielokrotnie dawał wyraz stanowisku, które można by streścić w określeniu: „nie ma formy bez normy”.

Przykładem są choćby orzeczenia dotyczące obowiązku dokumentowania stosunków związanych z umową ubezpieczenia. W kwestii formy, w jakiej powinna zostać wyrażona zgoda pracownika na objęcie go ubezpieczeniem pracowniczym od następstw nieszczęśliwych wypadków, SN stwierdził, że wobec braku jakichkolwiek norm (wynikających z ogólnych warunków ubezpieczenia lub wprost z regulacji kodeksowej umowy ubezpieczenia)

brak podpisu ubezpieczonego od następstw nieszczęśliwych wypadków na deklaracji zgody w sytuacji, gdy ubezpieczony wyrażał wolę przystąpienia do ubezpieczenia i opłacał składkę, nie powoduje nieważności umowy ubezpieczeniowej ${ }^{20}$.

Sąd ten uznał w szczególności, iż

przystąpienie do ubezpieczenia objętego powołanymi wyżej ogólnymi warunkami ubezpieczenia może być wyrażone przez każde takie zachowanie się pracownika (czyny konkludent-

18 Ibidem. Z. Radwański podkreślał równocześnie, że funkcja kontrolna nie powinna „prowadzić do ustanowienia utrudnień przekraczających racjonalne wymagania kontrolne, ponieważ wówczas forma zaczyna odgrywać szkodliwą dla obrotu gospodarczego rolę: sprzyjać obchodzeniu instytucji prawnych, które ten obrót organizują" (ibidem).

19 O dyskusji prowadzonej w trakcie prac kodyfikacyjnych zob. K. Górska, op. cit., s. 38-40 i przywołana tam literatura.

20 Uchwała SN z 29 maja 1978 roku III CZP 32/78; „Orzecznictwo Sądu Najwyższego, Izby Cywilnej, Pracy i Ubezpieczeń Społecznych” 1979, nr 3, poz. 45; Legalis; z aprobującą glosą T. Kwiecińskiego i A. Wąsiewicza, „Nowe Prawo” 1980, nr 4, s. 134 n.

Studia nad Autorytaryzmem i Totalitaryzmem 43, nr 4, 2021

(C) for this edition by CNS 
ne), które w sposób nie budzący wątpliwości wyraża tę wolę (art. 60 k.c.). Wyrazem takiego zamiaru jest w szczególności zgoda na potrącanie składek z przysługującego pracownikowi wynagrodzenia za pracę, odprowadzanych następnie do PZU, zwłaszcza gdy taki stan rzeczy trwa przez dłuższy czas.

Pogląd ten został podtrzymany przez SN w wyroku z 18 maja 1979 roku, w którym zostało stwierdzone, że

przewidziane w ogólnych warunkach ubezpieczenia następstw nieszczęśliwych wypadków, zatwierdzonych decyzją Ministra Finansów z dnia 11 lipca 1970 r., wymaganie podpisania tzw. deklaracji zgody przez osobę przystępującą do grupowego ubezpieczenia pracowników oznacza - wobec braku zastrzeżenia, że brak podpisu powoduje nieważność umowy ubezpieczeniowej - wprowadzenie dla tego oświadczenia woli formy pisemnej dla celów dowodowych (art. $74 \S 1$ k.c. $)^{21}$.

Z kolei w wyroku z 15 września 1977 Sąd Najwyższy zajął analogiczne stanowisko $\mathrm{w}$ odniesieniu do formy przystąpienia pracownika do zbiorowego ubezpieczenia rodzinnego na życie oraz formy składania rezygnacji z tegoż ubezpieczenia. Sąd wskazał wówczas, że postanowienia ogólnych warunków nie przewidują sankcji nieważności za niezachowanie formy pisemnej w przypadku tych czynności ${ }^{22}$. Warto zauważyć, że w uzasadnieniu tegoż wyroku znalazło się zdanie, iż „deklaracja zgody [...] i inne czynności dokonywane na piśmie, o których jest mowa w § 14-18 ogólnych warunków ubezpieczenia, spełniają jedynie funkcję ewidencyjno-porządkową". Okoliczność ta uniemożliwiała, zdaniem sądu, przypisywanie tym czynnościom wymogu formy pisemnej pod rygorem nieważności. Wydaje się, że z tego stwierdzenia wypływa również dalej idący wniosek, że wynikające z ogólnych warunków ubezpieczenia wymagania dotyczące dokumentowania opisanych czynności nie powinny być w ogóle traktowane jako obowiązek zachowania formy szczególnej, w tym również zastrzeżonej dla celów dowodowych.

Zasada swobody formy była również respektowana w innych stosunkach prawnych. Można tu wskazać między innymi wyrok SN z 22 sierpnia 1979 roku, w którym $\mathrm{w}$ odniesieniu do formy porozumienia między zakładami pracy o przejściu pracownika z jednego zakładu do drugiego stwierdzone zostało, że wobec braku zastrzeżenia w kodeksie pracy formy pisemnej dla takiego porozumienia „oświadczenie zakładów pracy $\mathrm{w}$ tym przedmiocie może być wyrażone przez każde zachowanie, które ich wolę ujawni w sposób dostateczny, a więc również i ustnie" ${ }^{23}$. Przedmiotowe orzeczenie miało kluczowe znaczenie dla ustalenia nabycia

21 III CRN 287/78; „Orzecznictwo Sądu Najwyższego, Izby Cywilnej, Pracy i Ubezpieczeń Społecznych" 1980, nr 1, poz. 8; Legalis.

22 II CR 297/77; „Orzecznictwo Sądu Najwyższego, Izby Cywilnej, Pracy i Ubezpieczeń Społecznych" 1978, nr 7, poz. 114; Legalis.

23 I PRN 102/79, „Orzecznictwo Sądu Najwyższego, Izby Cywilnej, Pracy i Ubezpieczeń Społecznych” 1980, nr 3, poz. 53; Legalis. 
przez pracownika prawa do dodatku za wysługę lat ${ }^{24}$. Z kolei w wyroku z 30 października 1979 roku SN odniósł się do formy umowy kooperacji w rolnictwie i także w tym wypadku doszedł do wniosku, że wobec braku szczegółowych unormowań ${ }^{25}$ zastosowanie mają przepisy kodeksu cywilnego, a umowa kooperacji zawarta w formie ustnej jest ważna ${ }^{26}$. Trzeba dostrzec, że sprawa dotyczyła sporu między rolnikiem indywidualnym a spółdzielnią kółek rolniczych, wyrok sądu, hołdujący wyrażonej w art. 60 k.c. zasadzie swobody formy, był zaś ukierunkowany na potrzebę wyjaśnienia wszystkich okoliczności istotnych dla rozstrzygnięcia bez stawiania w uprzywilejowanej sytuacji którejkolwiek ze stron.

\subsection{Tak zwana forma konkludentna}

W kontekście art. 60 k.c. SN wyrażał stanowisko o dopuszczalności tak zwanych konkludentnych (dorozumianych) oświadczeń woli. Możliwość niewerbalnego wyrażania oświadczeń woli, w sytuacji braku przepisów, z których mógłby wynikać obowiązek zachowania formy szczególnej, nigdy nie została zakwestionowana w judykaturze. Przeciwnie, da się odnotować szereg orzeczeń, w których konsekwentnie uznawane było za dopuszczalne wyrażanie woli przez każde, niekoniecznie sformalizowane, zachowanie się uczestnika obrotu. Co istotne, swoboda komunikacji w obrocie prawnym była respektowana bez względu na to, jakich stosunków dotyczyła oraz jaki status miały podmioty. W wyroku z 8 stycznia 1968 roku SN stwierdził, że

brak jest przepisu prawnego bądź postanowień statutu, z których wynikałoby, że umowa między spółdzielnią zaopatrzenia i zbytu a rzemieślnikiem-członkiem spółdzielni wymaga dla swej ważności formy pisemnej. Zgodnie więc z ogólnymi zasadami prawa umowa między stronami mogła dojść do skutku w każdej formie, nie wyłączając czynności konkludentnych, wyrażających się w takim zachowaniu się obu stron, które w sposób dostateczny ujawniło ich wolę zawarcia umowy określonej treści ${ }^{27}$.

W odniesieniu do formy potrącenia wyrażony został pogląd, że oświadczenie w tym zakresie może być złożone drugiej stronie, przy czym

${ }^{24}$ Nabycie tego dodatku następowało z uwzględnieniem poprzednich okresów pracy w jednostce uspołecznionej gospodarki rolnej, jeżeli przejście do pracy w jednostce kółek rolniczych nastąpiło na podstawie porozumienia między zakładami pracy.

25 SN miał tu na uwadze uchwałę Rady Ministrów z dnia 16 stycznia 1976 roku w sprawie rozwoju zespołu rolników indywidualnych, specjalizacji i kooperacji w rolnictwie (M.P. Nr 11, poz. 53), w której uregulowane były między innymi tak zwane umowy kooperacyjne.

26 II CR 355/79; „Orzecznictwo Sądu Najwyższego, Izby Cywilnej, Pracy i Ubezpieczeń Społecznych" 1980, nr 4, poz. 75; Legalis. Wobec tego stanowiska SN częściowo krytycznie wypowiedziano się w doktrynie (zob. L Kostórkiewicz, Glosa do wyroku SN z 30.10.1979 r., II CR 355/79, „Orzecznictwo Sądów Polskich i Komisji Arbitrażowych” $1981 \mathrm{nr} 4$, poz. 72).

27 II CR 300/67; Legalis. 
nie jest konieczne wyraźne stwierdzenie, iż dłużnik potrąca swoją wierzytelność z wierzytelnością drugiej strony, lecz wystarczy ujawnienie przez niego woli umorzenia obu wierzytelności przez ich wzajemne przeciwstawienie sobie ${ }^{28}$.

Podobnie zinterpretowano formę wezwania dłużnika do zapłaty, o czym mowa w art. 455 k.c. SN stwierdził, że wezwanie nie wymaga żadnej szczególnej formy — „wystarczy, jeżeli wierzyciel wyrazi w sposób dostateczny przez swoje zachowanie swoją wolę, aby dłużnik spełnił świadczenie"29. W wyroku z 28 sierpnia 1986 roku SN odniósł się z kolei do formy umowy o wykonanie lub wykorzystanie dzieła plastycznego, które w myśl przepisów wykonawczych do ustawy o prawie autorskim wymagało formy pisemnej ${ }^{30}$. Sąd wskazał, że jest to forma zastrzeżona dla celów dowodowych, zatem sama umowa może dojść do skutku również w sposób dorozumiany ${ }^{31}$.

Możliwość dorozumianego złożenia oświadczenia woli została jednak zakwestionowana przez SN w sytuacji, gdy strony umownie przewidziały wymóg zachowania formy szczególnej. W wyroku z 15 maja 1980 roku SN stwierdził, że

jeżeli strony w zamiarze zapobieżenia dorozumianemu kontynuowaniu dzierżawy (art. 694 k.c. w związku z art. 674 k.c.) zastrzegły w umowie, że ich oświadczenie woli co do przedłużenia powinno być dokonane pod rygorem nieważności na piśmie (art. 76 zdanie 1 k.c.), to niezachowanie tej formy wyłącza możność powoływania się przez dzierżawcę na wyrażenie przez wydzierżawiającego w jakikolwiek inny sposób (art. 60 k.c.) woli przedłużenia tej dzierżawy ${ }^{32}$.

W uzasadnieniu SN zabrakło niestety szerszego odniesienia się do znaczenia pactum de forma oraz możliwości zmiany umownych zastrzeżeń poczynionych przez strony co do formy dokonywanych przez nie czynności prawnych.

\subsection{Forma szczególna a forma dla celów administracyjnych}

W orzecznictwie SN dostrzeżono różnicę pomiędzy sytuacją, w której wymóg formy szczególnej wynika z przepisów prawa, a sytuacją, gdy przepisy takiego wymogu nie statuują, ale sformalizowanie czynności prawnej wiąże się z koniecznością dokonania jakiejś czynności urzędowej. Ciekawe orzeczenie zapadło w tym względzie w dniu 15 września 1986 roku w kontekście formy umowy sprzedaży samochodu ${ }^{33}$. Zgodnie $\mathrm{z}$ obowiązującym stanem prawnym taka umowa nie

28 III PZP 2/72; Legalis.

29 III CRN 2/72; Legalis.

${ }^{30}$ Chodziło o załącznik nr 1 rozporządzenia RM z dnia 11 listopada 1977 roku w sprawie zasad i stawek wynagrodzenia twórców dzieł plastycznych oraz umów o wykonanie lub wykorzystanie tych dzieł (Dz.U. z 1977 r. Nr 36, poz. 158) wydanego na podstawie art. 33 § 1 ustawy z dnia 10 lipca 1952 roku o prawie autorskim (Dz.U. z 1952 r. Nr 34, poz. 234).

31 I CR 320/86; Legalis.

32 II CR 110/80; „Orzecznictwo Sądu Najwyższego, Izby Cywilnej, Pracy i Ubezpieczeń Społecznych" 1980/11/222.

33 III CRN 198/86; Legalis. 
wymagała zachowania żadnej formy szczególnej. Spór między stronami powstał jednak w związku z faktem, że po zawarciu umowy w formie ustnej, sprzedający odmówili wydania dokumentu poświadczającego fakt kupna, co uniemożliwiło nabywcom rejestrację pojazdu na ich nazwisko ${ }^{34}$. W istocie rzeczy chodziło o brak udokumentowanego dowodu nabycia własności rzeczy przy jednoczesnym braku podstaw do zakwestionowania ważności lub skuteczności umowy sprzedaży. SN uznał w tej sytuacji, że jeżeli zachowanie formy pisemnej niezbędne jest dla dopełnienia czynności administracyjnej tego rodzaju, jak wydanie dowodu rejestracyjnego samochodu na nazwisko nowego jego nabywcy, a kontrahent odmawia sporządzenia w formie pisemnej umowy kupna-sprzedaży, to sytuacja taka uzasadnia skorzystanie z powództwa o ustalenie na podstawie art. 189 k.c. Sąd Najwyższy stwierdził nadto, że „wyrok ustalający, że strony zawarły umowę kupna-sprzedaży, zastępuje w tym wypadku formę pisemną wymaganą dla wywołania dalszych skutków w dziedzinie prawa administracyjnego".

\subsection{Orzeczenie sądowe lub administracyjne jako tak zwana forma zastępcza}

Wcześniej opisana możliwość udokumentowania faktu nieformalnego dokonania czynności prawnej $\mathrm{w}$ postaci orzeczenia sądowego korelowała $\mathrm{z}$ innym poglądem, który zakładał, iż w niektórych przypadkach orzeczenie sądowe lub administracyjne może stanowić zastępczą formę w stosunku do wymogu zachowania formy szczególnej.

Takie zapatrywanie SN zostało wyrażone na gruncie art. 64 k.c. oraz art. 1047 k.p.c., dotyczących stwierdzenia przez sąd obowiązku złożenia oświadczenia wolii ${ }^{35}$. Przyjęto, że wyrok sądu zastępuje formę tego oświadczenia woli, którego obowiązek złożenia sąd stwierdza. Jednak w przypadkach stwierdzenia obowiązku zawarcia umowy przyrzeczonej w umowie przedwstępnej oraz w wypadkach, gdy sąd uwzględnia powództwo o stwierdzenie obowiązku zawarcia umowy całkowicie zgodnie z żądaniem powoda, orzeczenie sądu stwierdza zawarcie umowy i zastępuje tę umowę, czyniąc tym samym zadość ewentualnemu wymogowi zachowania formy szczególnej.

W orzecznictwie dopuszczono również możliwość zastąpienia wymogu formy szczególnej przez czynność administracyjną. Między innymi taki pogląd został wyrażony w postanowieniu SN z 14 września 1965 roku w odniesieniu do

34 Zgodnie bowiem z ówcześnie obowiązującymi przepisami przy zarejestrowaniu pojazdu wnioskodawca miał przedstawić między innymi dokument kupna-sprzedaży (§ 3 ust. 1 pkt 1 i $\S 4$ ust. 1 pkt 4 rozporządzenia Ministra Komunikacji z dnia 29 grudnia 1983 roku w sprawie rejestracji, ewidencji i oznaczania pojazdów; Dz.U. z 1984 r. Nr 1, poz. 2 w zw. z art. 62 ust. 1 pkt 1 ustawy z dnia 1 lutego 1983 roku — Prawo o ruchu drogowym, Dz.U. z 1983 r. Nr 6, poz. 35).

35 Tak SN między innymi w uchwale z dnia 7 stycznia 1967 roku, III CZP 32/66, „Orzecznictwo Sądu Najwyższego. Izba Cywilna” 1968, nr 12, poz. 199. 
ustanowienia prawa użytkowania wieczystego ${ }^{36}$. W uzasadnieniu tego wyroku SN wyraził jednak zapatrywanie, że sytuacje tego rodzaju, choć dopuszczalne, powinny znajdować swoje umocowanie normatywne. Innymi słowy: decyzja administracyjna może zastąpić czynność prawną, a wraz z tym czynić zadość wymaganej formie szczególnej, ale tylko w takich wypadkach, w których przepisy uprawniają do wydania władczego rozstrzygnięcia określonej sprawy ${ }^{37}$.

\subsection{Przesłanki dochowania formy szczególnej}

Analiza judykatury SN w części poświęconej stosowaniu przepisów określających obowiązek zachowania formy szczególnej skłania do postawienia tezy przeciwnej do tej, która odzwierciedlała wykładnię art. 60 k.c. W tym bowiem przypadku SN respektował zasadę: ,jest norma, musi być i forma”.

Ocena dochowania formy szczególnej była wobec tego dokonywana w sposób restryktywny. Miało być przede wszystkim jasne, że jeśli przepis wymaga zachowania formy szczególnej, to wymóg ten jest spełniony tylko wtedy, gdy w owej formie obie strony złożą swoje oświadczenia woli. Wyrazem tego był między innymi pogląd, iż „oświadczenie pisemne zawarte na dokumencie zwanym wekslem, będące podstawą zobowiązania wekslowego, nie jest umową, lecz jednostronną czynnością prawną”, zatem „wystawienie przez osobę trzecią i wręczenie wierzycielowi weksla własnego nie czyni zadość wymaganiu formy pisemnej, przewidzianej w art. 522 k.c. dla umowy o przejęcie długu"38.

Ścisłe interpretowanie przepisów określających przesłanki dochowania formy szczególnej, z zasady wykluczało również możliwość rozszerzenia lub ograniczenia ich stosowania ze względów słusznościowych (na przykład zasady współżycia społecznego w PRL) lub celowościowych (na przykład urzeczywistnianie socjalistycznych zasad gospodarki centralnej).

36 III CR 171/65; „Orzecznictwo Sądu Najwyższego, Izby Cywilnej, Pracy i Ubezpieczeń Społecznych" 1966 , nr 7-8, poz. 121, str. 56, Legalis. Orzeczenie SN zapadło między innymi na tle obowiązującej w tym czasie ustawy z dnia 14 lipca 1961 roku o gospodarce terenami w miastach i osiedlach (Dz.U. z 1961 r. Nr 32, poz. 159). Jej art. 14 ust. 1 stanowił, że ,ustanowienie i przedłużenie prawa wieczystego użytkowania następuje w drodze umowy zawartej w formie aktu notarialnego, który stanowi podstawę wpisu do księgi wieczystej”. W uzasadnieniu SN wskazał, że umowa o przeniesienie własności nieruchomości powinna być pod nieważnością zawarta $\mathrm{w}$ formie aktu notarialnego, jednak w praktyce zrównuje się z tą formą ugodę sądową, a z mocy szczególnych przepisów własność nieruchomości można uzyskać na zasadzie orzeczenia władzy administracyjnej (nadanie gruntu w trybie reformy rolnej i inne podobne wypadki uwłaszczenia). Jak stwierdził SN ,żadne argumenty logiczne nie przemawiają za tym, aby inaczej traktować ustanowienie wieczystego użytkowania, które przecież jest prawem o nieco węższym zakresie niż własność".

37 SN wskazał jako przykład takich sytuacji nadanie własności gruntu w trybie reformy rolnej lub przypadki wywłaszczenia.

38 Uchwała SN z 17 października 1979 roku, III CZP 68/79; „Orzecznictwo Sądu Najwyższego, Izby Cywilnej, Pracy i Ubezpieczeń Społecznych” 1980, nr 4, poz. 67; Legalis. 
W uchwale z 22 grudnia 1980 roku SN uznał, że na podstawie przepisów regulujących formę umowy przekazania gospodarstwa rolnego następcy w zamian za emeryturę lub rentę ${ }^{39}$ umowa taka powinna być pod rygorem nieważności sporządzona przed naczelnikiem gminy lub osobą będącą jego zastępcą, zaś niedopuszczalne jest jej zawarcie przez pracownika urzędu posiadającego upoważnienie wystawione przez naczelnika gminy ${ }^{40}$. Podobnie ścisłej wykładni SN poddał przesłanki sporządzenia testamentu ustnego (art. 952 k.c.) w uchwale z 20 września 1968 roku, w której uznał, że do jego ważności konieczne jest ustne oświadczenie woli spadkodawcy. Zatem nie wystarcza ujawnienie woli w inny sposób ani też podpisanie przez spadkodawcę pisemnego projektu testamentu przygotowanego przez inną osobę ${ }^{41}$.

Natomiast przykładem odstępstwa od ścisłej, literalnej wykładni przepisów dotyczących przesłanek formy szczególnej jest wyrok SN z 21 czerwca 1966 ro-ku. Został w nim wyrażony pogląd, iż do zachowania pisemnej formy jednostronnej czynności prawnej konieczne jest doręczenie adresatowi oświadczenia dokumentu obejmującego treść oświadczenia woli, przy czym nie wystarczy tu samo okazanie pisma. Jak bowiem wskazano w uzasadnieniu, intencją przepisów o formie jest zapewnienie stronie możliwości dysponowania dokumentami

39 SN orzekał na podstawie art. 52 ust. 1 ustawy z dnia 27 października 1977 roku o zaopatrzeniu emerytalnym rolników i ich rodzin (Dz.U. z 1977 r. Nr 32, poz. 130), który stanowił, iż „przekazanie gospodarstwa rolnego następcy następuje w drodze umowy pisemnej sporządzonej przez naczelnika gminy". Jak wskazano w uzasadnieniu, przepis ten stanowi przypadek upoważnienia przez ustawodawcę organu administracji państwowej do sporządzenia czynności prawnej, przy czym wybór osoby uprawnionej wiąże się z uznaniem jej za osobę zaufania publicznego.

40 Uchwała SN (7) - o mocy zasady prawnej, III CZP 39/80; ,Orzecznictwo Sądu Najwyższego, Izby Cywilnej, Pracy i Ubezpieczeń Społecznych” 1981, nr 7, poz. 121; Legalis.

${ }^{41}$ III CZP 85/68; OSNCP $1969 \mathrm{Nr} 6$, poz. 102, Legalis. SN podjął powyższą uchwałę w odpowiedzi na pytanie prawne: ,czy do ważności testamentu sporządzonego na podstawie art. $952 \S 1$ k.c. konieczne jest, żeby spadkodawca oświadczył ostatnią wolę ustnie, to jest przez wypowiedzenie słów obejmujących pełną treść testamentu, czy też wystarcza, by uczynił to za pomocą pewnych gestów lub znaków, w szczególności przez podpisanie przygotowanego uprzednio bez jego udziału i następnie odczytanego mu pisemnego projektu testamentu?". SN zwrócił przy tym uwagę, że nawet wzgląd na osoby głuchonieme nie może doprowadzić do wykładni sprzecznej z brzmieniem art. $952 \S 1$ k.c. Wart przytoczenia jest fragment uzasadnienia tej uchwały, w której stwierdzone zostało, iż ,potwierdzeniem potrzeby dosłownego rozumienia ustawowego wymagania ustnego wyrażania woli są poruszane w literaturze względy, że testament jest aktem formalnym, prawnie bardzo doniosłym, a zatem wymagającym dojrzałej decyzji testatora i dokładnego ustalenia treści testamentu, że świadkowie powinni się przekonać przy testowaniu, iż spadkodawca świadomie i swobodnie wyraża swą wolę, i że należy świadkom umożliwić — przez ewentualne pytanie skierowane do testatora - właściwe zrozumienie jego oświadczeń. Nie ulega wątpliwości, że dopuszczenie oświadczenia woli przez pewne konkludentne zachowanie się czy nawet przez podpisanie projektu testamentu sporządzonego przez inną osobę przeczyłoby powyższym założeniom". Trzeba jednak odnotować, że rozluźnienie tej ścisłej wykładni nastąpiło w przypadku formy testamentu własnoręcznego w zakresie treści podpisu złożonego pod rozrządzeniem testatora uchw. SN (7) zasada prawna z dnia 28 kwietnia 1973 roku, III CZP 78/72, „Orzecznictwo Sądu Najwyższego, Izby Cywilnej, Pracy i Ubezpieczeń Społecznych” 1973, nr 12, poz. 207; Legalis. 
zawierającymi treść czynności prawnej ${ }^{42}$. Wyrok ten stanowi jeden z nielicznych przypadków, w których SN przy ustalaniu przesłanek zachowania formy pisemnej oświadczenia woli tak ewidentnie kierował się względami celowościowymi ukierunkowanymi na funkcje dowodowe tej formy ${ }^{43}$.

\subsection{Treść czynności prawnej a zakres obowiązku formy}

Jednym z istotnych wątków dotyczących realizacji formy szczególnej były rozważania SN poświęcone zakresowi obowiązku formy w kontekście treści oświadczenia woli.

W wyroku z 25 maja 1988 roku SN odniósł się do elementów treści umowy kontraktacji, która to umowa powinna być zawarta $\mathrm{w}$ formie pisemnej pod rygorem nieważności ${ }^{44}$. SN ze względu na doniosłość ekonomiczno-prawną tego typu umów przyjął, iż wynikająca z art. 616 k.c. forma pisemna „ma doprowadzić do zawarcia konkretnej umowy, która indywidualnie charakteryzować będzie elementy przedmiotowo istotne dla każdej ze stron powstałego tą drogą stosunku zobowiązaniowego”. Z tego względu SN stwierdził, że „nie można zrezygnować, aby umowa kontraktacji nie obejmowała swoją treścią dokładnego oznaczenia elementów przedmiotowo istotnych". Na tej podstawie można by wnioskować, że po pierwsze — jeśli dla dokonania czynności prawnej wymagana jest forma szczególna, to realizacja tego wymogu wiąże się z koniecznością wyrażenia w tej formie co najmniej elementów przedmiotowo istotnych treści czynności prawnej; po drugie - elementy te powinny zostać dokładnie oznaczone. Jak bowiem dalej wskazał SN:

jeżeli zdarzy się, że elementy (przedmiotowo istotne) nie będą dokładnie oznaczone, np. ilość świadczenia zawyżona będzie zaniżona, świadczenie inaczej określone, wówczas dowód zmierzający do wykazania, jaka była rzeczywista treść czynności prawnej, jest dowodem przeciwko osnowie dokumentu i jako taki musi napotkać na ograniczenia przewidziane w przepisie art. $247 \mathrm{KPC}$.

W ten sposób SN akcentował znaczenie formy szczególnej dla uchylenia wątpliwości co do dokonania czynności prawnej i związanej z tym pewności obrotu, a ponadto zwracał uwagę na jej funkcję dowodową.

Trzeba odnotować, że w judykaturze nie zawsze konsekwentnie wiązano spełnienie wymogu formy szczególnej z koniecznością wyrażenia w niej elementów przedmiotowo istotnych czynności prawnej. W wyroku z 26 maja 1983 roku SN uznał, iż

42 III PR 18/65; „Nowe Prawo” 1966, nr 4; Legalis.

43 Stanowisko SN zostało poddane gruntownej krytyce (zob. glosa do tego orzeczenia M. Piekarskiego, NP 1966, nr 4) i nie znalazło reprezentacji w późniejszym orzecznictwie.

44 II CR 129/88; Legalis. 1966, Nr 4. 
forma materialna umowy pozornej służy jednocześnie umowie ukrytej, co oznacza, że do ważności ukrytej umowy, dla której ustawa zastrzega formę szczególną pod rygorem nieważności, wystarcza, żeby umowa pozorna była zawarta w tej formie ${ }^{45}$.

Wyrok ten stał się podstawą zapatrywania, że pozorna czynność prawna niejako „użycza” swojej formy czynności ukrytej, bez względu na to, że elementy treści czynności dysymulowanej nie zostały w tej formie ujęte. Pogląd SN stał w kontrze nie tylko wobec dowodowych funkcji formy, lecz także nie sprzyjał pewności obrotu, przez co stwarzał pole do obchodzenia przepisów wymagających zachowania formy szczególnej ${ }^{46}$. Zupełnie też nie respektował kontrolnej funkcji formy szczególnej. Omawiane stanowisko SN trudno inaczej wytłumaczyć, jak potrzebą stabilizacji stosunków prawnych ukształtowanych w następstwie takich „ukrytych” czynności prawnych, zwłaszcza że w przeważającej większości dotyczyły one stosunków gruntowych.

\subsection{Konwersja czynności prawnej nieważnej z powodu braku formy}

W obszarze analizy skutków niedochowania formy szczególnej pojawił się problem dopuszczalności konwersji czynności prawnej nieważnej z uwagi na brak formy w inną ważną czynność. Poglądy wyrażane w tym zakresie przez SN nie pozwalają uznać, że doszło do ukształtowania generalnego stanowiska w tej kwestii. Po pierwsze, SN wypowiadał się w odniesieniu do konkretnych zdarzeń. Wyrażane poglądy nie miały zatem bardziej uniwersalnego charakteru. Po drugie, stanowisko SN w tym zakresie nie było jednolite. I tak na przykład w wyroku z 17 grudnia 1966 roku SN nie wykluczył możliwości konwertowania umowy licencyjnej zawartej bez wymaganej pod rygorem nieważności formy pisemnej. Stwierdził, że

brak formy pisemnej wymienionej umowy ma tylko ten skutek, że nie stanowi ona umowy licencyjnej, co nie wyłącza możliwości oceny jej skutków — na podstawie przepisów prawa cywilnego — jak każdej umowy nienazwanej ${ }^{47}$.

Natomiast całkowicie odmienny pogląd wypowiedział w postanowieniu z 2 grudnia 1971 roku. W tym wypadku stwierdzono, że umowa licencyjna zawarta bez zachowania formy wymaganej pod rygorem nieważności nie może być uznana za

45 II CR 32/83, „Nowe Prawo” 1985, nr 2, s. 116; Legalis z aprobującą glosą M. Kępińskiego, „Nowe Prawo” 1985, nr 2.

46 Po transformacji ustrojowej stanowisko to zostało zakwestionowane w orzecznictwie SN — zob. wyrok SN z 12 października 2001 roku, V CKN 631/00, „Orzecznictwo Sądu Najwyższego. Izba Cywilna” 2002, nr 7-8, poz. 91; uchwała SN z 22 maja 2009 roku, III CZP 21/09, „Orzecznictwo Sądu Najwyższego. Izba Cywilna” 2010, nr 1, poz. 13; uchwała SN z 9 grudnia 2011 roku, III CZP 79/11, „Orzecznictwo Sądu Najwyższego. Izba Cywilna” 2012, nr 6, poz. 74.

47 I CR 447/66; „Orzecznictwo Sądu Najwyższego, Izby Cywilnej, Pracy i Ubezpieczeń Społecznych” 1967, nr 9, poz. 153; Legalis. 
ważną jako umowa nienazwana ${ }^{48}$. Pogląd o dopuszczalności konwersji ugruntował się zaś w orzecznictwie na gruncie prawa spadkowego w kontekście wadliwie sporządzonego testamentu allograficznego, który w opinii SN można było jednak uznać za ważny testament ustny ${ }^{49}$. U podstaw dopuszczalności konwersji w tym przypadku leżało przekonanie o szczególnej — na gruncie prawa spadkowego potrzebie ochrony woli stron ${ }^{50}$.

Innej sytuacji dotyczyło postanowienie z 3 października 1980 roku, w którym SN odniósł się do możliwości zbycia spadku lub udziału w spadku w drodze oświadczenia złożonego przed sądem $\mathrm{w}$ ramach postępowania o dział spadku. Zdaniem SN, takie oświadczenie jest nieważne wobec braku wymaganej na podstawie art. $1052 \S 3$ k.c. formy aktu notarialnego, jednak może być uznane „za wniosek uczestnika postępowania wyrażający jego wolę co do sposobu dokona-

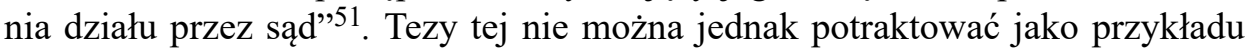
konwersji, bowiem stanowiące czynność procesową oświadczenie uczestników postępowania działowego nie jest wiążące dla sądu i nie prowadzi bezpośrednio do wywołania skutków w sferze prawa materialnego.

\subsection{Skutki dowodowe niedochowania formy szczególnej}

Poza dyskusją, również na poziomie orzecznictwa, pozostawało to, że następstwem niedochowania formy zastrzeżonej ad solemnitatem jest bezwzględna nieważność czynności prawnej. Sąd Najwyższy, respektując w pełni ten skutek, zwrócił przy okazji uwagę na dowodowy aspekt formy zastrzeżonej pod rygorem

48 II CZ 175/71; „Orzecznictwo Sądów Polskich i Komisji Arbitrażowych” 1973 nr 12, poz. 243, Legalis, z aprobującą glosą R. Markiewicza, Glosa do post. SN z 2.12.1971 r., II CZ 176/71, „Orzecznictwo Sądów Polskich i Komisji Arbitrażowych” 1973 nr 12, poz. 243, s. 528530. Trzeba odnotować, że zagadnienie konwersji czynności prawnej nieważnej z uwagi na brak formy było również dość rozbieżnie postrzegane wśród przedstawicieli doktryny prawa (zob. w tym zakresie R. Markiewicz, op. cit., s. 529).

49 W uchwale SN z dnia 22 marca 1971 roku, III CZP 91/70 („Orzecznictwo Sądu Najwyższego, Izby Cywilnej, Pracy i Ubezpieczeń Społecznych” 1971, nr 10, poz. 168) stwierdzono, że „okolicznością szczególną w rozumieniu art. $952 \S 1$ k.c. może być także niezachowanie ze strony właściwego funkcjonariusza prezydium rady narodowej przepisu prawa, powodujące nieważność testamentu zwykłego z art. 951 k.c. To zaś wystarcza do uznania, że nastąpiło spełnienie pierwszej przesłanki dopuszczalności sporządzenia testamentu szczególnego, jakim jest testament ustny”. Zob. również uchwała SN z 9 lutego 1981 roku (III CZP 68/80, „Orzecznictwo Sądu Najwyższego, Izby Cywilnej, Pracy i Ubezpieczeń Społecznych" 1981, nr 6, poz. 103) oraz uchwała SN z 22 marca 1982 roku (III CZP 5/82, „Orzecznictwo Sądu Najwyższego, Izby Cywilnej, Pracy i Ubezpieczeń Społecznych” 1982, nr 8-9, poz. 117 z krytyczną glosą A. Proksy, „Nowe Prawo” 1984, nr 3, str. 113 n.), w których dopuszczono możliwość uznania za testament ustny woli oświadczonej, odpowiednio, wobec kierownika Urzędu Stanu Cywilnego i sołtysa.

50 Zob. na ten temat M. Grochowski, Skutki braku zachowania formy szczególnej oświadczenia woli, Warszawa 2017, s. 67 n.

51 III CRN 180/80; „Orzecznictwo Sądu Najwyższego, Izby Cywilnej, Pracy i Ubezpieczeń Społecznych" 1981, nr 2-3, poz. 45; Legalis. 
nieważności i wykluczył — w razie jej niedochowania — możliwość dopuszczenia przed sądem innych dowodów na okoliczność dokonania czynności prawnej ${ }^{52}$.

W wypowiedziach SN poświęconych stosowaniu formy dla celów dowodowych zwraca z kolei uwagę tendencja do osłabiania skutków niedochowania tej formy dyktowana potrzebą poznania prawdy obiektywnej. Wyrażało się to w stosunkowo liberalnym traktowaniu przesłanek uprawniających do uchylenia ograniczeń dowodowych. Między innymi w odniesieniu do wskazanego w art. 74 $\S 2$ zd. 1 k.c. pisma uprawdopodabniającego fakt zawarcia umowy SN stwierdził, że nie jest konieczne, aby pochodziło ono od strony, przeciwko której dowód taki ma być prowadzony, ani też, aby było podpisane przez jedną ze stron ${ }^{53}$.

Podstawowe znaczenie miała jednak wykładnia art. $74 \S 2$ zd. 2 k.c., na podstawie którego sąd lub państwowa komisja arbitrażowa mogły dopuścić dowody dokonania czynności prawnej pochodzące z przesłuchania stron lub z zeznań świadków, jeżeli ze względu na szczególne okoliczności sprawy uznały to za konieczne. Ta niedookreślona przesłanka łagodzenia wynikającego z formy ad probationem rygoru dowodowego stała się przedmiotem licznych wypowiedzi judykatury. Przede wszystkim, jak zwrócono uwagę, możliwość tolerowania ujemnych następstw wynikających dla strony z ograniczeń dowodowych mogła zachodzić tylko w tych przypadkach ,gdy nie koliduje to z zasadami współżycia społecznego i interesem państwa oraz da się pogodzić z podstawowymi zasadami wymiaru sprawiedliwości w sprawach cywilnych" 54 . W tym kontekście w orzecznictwie wskazano szereg sytuacji, w których na sądzie spoczywa szczególny obowiązek poznania prawdy obiektywnej. Należały do nich sprawy, w których jedną ze stron była jednostka gospodarki uspołecznionej, sprawy alimentacyjne oraz sprawy odszkodowawcze. Za szczególne okoliczności przemawiające za koniecznością dopuszczenia przez sąd dowodów osobowych na fakt nieformalnej czynności prawnej uznano również sytuację, w której należało poddać ochronie osobę niebędącą jednostką gospodarki uspołecznionej, o słabej znajomości przepisów prawa, gdy jej niewiedza o obowiązku udokumentowania czynności prawnej została wykorzystana przez drugą stroną. Podobnie liberalne podejście przyjęto w sytuacji, gdy nieformalna czynność prawna została dokonana „między członkami komórki społecznej, darzącymi się — z uwagi na więź grupową — wyjątkowym zaufaniem, a więc pomiędzy członkami rodziny i najbliższymi krewnymi" ${ }^{55}$. Za szczególne okoliczności w rozumieniu

52 Tak między innymi w uchwale SN z 17 października 1979 roku (III CZP 68/79), w której stwierdzono, że dopuszczenie dowodów na okoliczność umowy zawartej bez zachowania wymaganej pod rygorem nieważności formy pisemnej nie jest możliwe, gdyż prowadziłoby do obejścia przepisów o formie zastrzeżonej pod rygorem nieważności (art. 247 k.p.c.).

53 Wyrok SN z 18 maja 1979 roku, III CRN 287/78; „Orzecznictwo Sądu Najwyższego, Izby Cywilnej, Pracy i Ubezpieczeń Społecznych” 1980, nr 1, poz. 9; Legalis.

54 Z uzasadnienia uchwały SN z dnia 8 sierpnia 1986 roku, III CZP 45/86, „Orzecznictwo Sądu Najwyższego, Izby Cywilnej, Pracy i Ubezpieczeń Społecznych” 1987, nr 7, poz. 95; Legalis.

55 Ibidem. W glosie, zasadniczo aprobującej, do tej uchwały Sądu Najwyższego A. Szpunar wskazał, że analogicznie liberalne stanowisko prezentuje orzecznictwo francuskie (idem, Glosa do 
art. $74 \S 2$ zd. 2 k.c. została nadto uznana sytuacja ujęta w art. 246 k.c., to jest gdy dokument obejmujący czynność prawną został zgubiony, zniszczony lub zabrany przez osobę trzecią ${ }^{56}$.

\section{Wnioski}

Orzecznictwo SN w latach 1964-1989 nie wpłynęło na maksymalizację wymogów formalnych wynikających z kodeksu cywilnego.

W wykładni art. 60 k.c. pojawiające się wątpliwości były rozstrzygane na rzecz zasady swobody formy. Można by wręcz stwierdzić, że SN kierował się w tym względzie swoistą dyrektywą interpretacyjną in dubio pro libertate. Szeroko dopuszczano również możliwość dorozumianego składania oświadczenia woli we wszystkich przypadkach, w których ani z przepisu prawa, ani z woli stron nie wynikał obowiązek zachowania formy szczególnej.

$\mathrm{Na}$ stanowisko SN w tej kwestii nie miał wpływu status strony czynności prawnej, w tym interes podmiotu będącego jednostką gospodarki uspołecznionej. Przy braku ustawowego wymogu formy szczególnej SN nie znajdował podstaw do kwestionowania ważności lub skuteczności dokonanych nieformalnie czynności prawnych, nawet jeśli konieczność ich dokumentowania wiązała się z potrzebą dokonania jakiejś czynności administracyjnej. Strony mogły jednak uzyskać dowód dokonania czynności w postaci wyroku uwzględniającego powództwo o ustalenie w trybie art. 189 k.p.c. Jednocześnie w orzecznictwie nie znalazło się miejsce dla tezy o generalnej dopuszczalności zastąpienia wymogu formy szczególnej w postaci orzeczenia sądowego lub administracyjnego. Aby taki skutek mógł nastąpić, uprawnienie do działania dla sądu lub organu administracji państwowej musiało mieć umocowanie w ustawie. Podobnie dopuszczalność konwersji nieformalnej czynności prawnej została uznana tylko wyjątkowo w oznaczonych okolicznościach i tylko dla ochrony woli stron.

Interpretacja przepisów regulujących przesłanki dochowania formy szczególnej była w zdecydowanej większości przypadków dokonywana w sposób ścisły, bez śladu wpływu ideologii państwa socjalistycznego. Między innymi wskutek tego nie doszło w orzecznictwie do rozszerzenia kręgu podmiotów, które ze strony przedstawicieli administracji państwowej byłyby uprawnione do dokonywania czynności prawnych.

Funkcja kontrolna formy czynności prawnych nie miała dominującego znaczenia przy wykładni przepisów o formie. Większe znaczenie przypisywano raczej takim funkcjom formy, jak uchylenie wątpliwości co do dokonania czynności prawnych czy zapewnienie pewności obrotu. Niebagatelne znaczenie miała również funkcja dowodowa formy czynności prawnych. W tym właśnie obszarze

uchwaly SN z dnia 08.08.1986 r., III CZP 45/86, „Państwo i Prawo” 1988, nr 4, s. 140).

56 Wyrok SN z 12 grudnia 1973 roku, II CR 668/73, Legalis. 
widać w orzecznictwie tendencję do uprzywilejowywania zasady prawdy obiektywnej, leżącej u podstaw socjalistycznego postępowania cywilnego. Także jednak i w tym zakresie dążenie do jej realizacji nie prowadziło do obchodzenia przepisów o formie zastrzeganej pod rygorem nieważności, a jedynie do łagodzenia rygoru niedochowania formy dla celów dowodowych.

Reasumując: przegląd wyżej opisanych wątków judykatury nie stanowi podstawy do postawienia tezy, że przepisy o formie czynności prawnych były stosowane w okresie PRL w sposób, który czyniłby z nich nadzwyczajny instrument kontroli obrotu. Sąd Najwyższy w swoim orzecznictwie dawał najczęściej świadectwo kontynuowania dobrej, klasycznej myśli prawa cywilnego. W konsekwencji większość ukształtowanych w tamtym okresie poglądów zachowała swoją aktualność.

\section{Bibliografia}

\section{Literatura}

Górska K., O perspektywie zniesienia formy pisemnej dla celów dowodowych, „Rejent” 2008, nr 12. Grochowski M., Forma oświadczenia woli dla celów dowodowych — enfant terrible polskiej cywilistyki, [w:] Profesor Aleksander Wolter - w 105. rocznice urodzin, red. M. Grochowski, Lublin 2010.

Grochowski M., Skutki braku zachowania formy szczególnej oświadczenia woli, Warszawa 2017.

Grzybowski S., [w:] System prawa cywilnego, t. 1. Część ogólna, Wrocław 1974.

Kępiński M., Glosa do wyroku SN z 26.05.1983 r., II CR 32/83, „Nowe Prawo” 1985, nr 2.

Kostórkiewicz L., Glosa do wyroku SN z 30.10.1979 r., II CR 355/79, „Orzecznictwo Sądów Polskich i Komisji Arbitrażowych" 1981, nr 4, poz. 72.

Kwieciński T., Wąsiewicz A., Glosa do uchwały SN z 29.5.1978 r. III CZP 32/78, „Nowe Prawo” 1980 , nr 4.

Machnikowska A., Wplyw ustawodawstwa stanu wojennego na prawo cywilne w Polsce, „Studia nad Autorytaryzmem i Totalitaryzmem" 2017, nr 3.

Markiewicz R., Glosa do post. SN z 2.12.1971 r., II CZ 176/71, „Orzecznictwo Sądów Polskich i Komisji Arbitrażowych" 1973, nr 12, poz. 243.

Piekarski M., Glosa do wyroku SN z 21.06.1965 r., III PR 18/65, „Nowe Prawo” 1966, nr 4.

Proksa A., Glosa do uchwaty SN z 22.3.1982 r., III CZP 5/82, „Nowe Prawo” 1984, nr 3.

Radwański Z., [w:] System prawa cywilnego, t. 1. Część ogólna, red. S. Grzybowski, Wrocław 1985.

Radwański Z., Prawo cywilne PRL, „Czasopismo Prawno-Historyczne” 1995, z. 1-2.

Szpunar A., Glosa do uchwaty SN z dnia 08.08.1986 r., III CZP 45/86, „Państwo i Prawo” 1988, $\mathrm{nr} 4$.

Szpunar A., Uwagi o formie przewidzianej dla celów dowodowych, „Ruch Prawniczy, Ekonomiczny i Socjologiczny" 1987, z. 4.

\section{Orzecznictwo}

Postanowienie SN z 14 września 1965 roku, III CR 171/65; „Orzecznictwo Sądu Najwyższego, Izby Cywilnej, Pracy i Ubezpieczeń Społecznych" 1966, nr 7-8, poz. 121, Legalis.

Postanowienie SN z 2 grudnia 1971 roku, II CZ 175/71; „Orzecznictwo Sądów Polskich i Komisji Arbitrażowych" 1973, nr 12, poz. 243, Legalis.

Studia nad Autorytaryzmem i Totalitaryzmem 43, nr 4, 2021

(C) for this edition by CNS 
Postanowienie SN z 9 marca 1972 roku, III PZP 2/72; Legalis.

Postanowienie SN z 3 października 1980 roku, III CRN 180/80; „Orzecznictwo Sądu Najwyższego, Izby Cywilnej, Pracy i Ubezpieczeń Społecznych” 1981, nr 2-3, poz. 45; Legalis.

Uchwała SN z 7 stycznia 1967 roku, III CZP 32/66, „Orzecznictwo Sądu Najwyższego. Izba Cywilna" 1968 , nr 12, poz. 199.

Uchwała SN z 20 września 1968 roku, III CZP 85/68; „Orzecznictwo Sądu Najwyższego, Izby Cywilnej, Pracy i Ubezpieczeń Społecznych" 1969, nr 6, poz. 102, Legalis.

Uchwała SN (7) — zasada prawna z dnia 22 marca 1971 roku, III CZP 91/70, „Orzecznictwo Sądu Najwyższego, Izby Cywilnej, Pracy i Ubezpieczeń Społecznych” 1971, nr 10, poz. 168.

Uchwała SN (7) - zasada prawna z dnia 28 kwietnia 1973 roku, III CZP 78/72, „Orzecznictwo Sądu Najwyższego, Izby Cywilnej, Pracy i Ubezpieczeń Społecznych” 1973, nr 12, poz. 207, Legalis.

Uchwała SN z 29 maja 1978 roku, III CZP 32/78, „Orzecznictwo Sądu Najwyższego, Izby Cywilnej, Pracy i Ubezpieczeń Społecznych” 1979, nr 3, poz. 45; Legalis.

Uchwała SN z 17 października 1979 roku, III CZP 68/79; „Orzecznictwo Sądu Najwyższego, Izby Cywilnej, Pracy i Ubezpieczeń Społecznych” 1980, nr 4, poz. 67; Legalis.

Uchwała SN (7) — zasada prawna z 22 grudnia 1980 roku, III CZP 39/80; „Orzecznictwo Sądu Najwyższego, Izby Cywilnej, Pracy i Ubezpieczeń Społecznych” 1981, nr 7, poz. 121; Legalis.

Uchwała SN z 9 lutego 1981 roku; III CZP 68/80, „Orzecznictwo Sądu Najwyższego, Izby Cywilnej, Pracy i Ubezpieczeń Społecznych" 1981, nr 6, poz. 103.

Uchwała SN z 22 marca 1982 roku ,III CZP 5/82, „Orzecznictwo Sądu Najwyższego, Izby Cywilnej, Pracy i Ubezpieczeń Społecznych” 1982, nr 8-9, poz. 117.

Uchwała SN z dnia 8 sierpnia 1986 roku, III CZP 45/86, „Orzecznictwo Sądu Najwyższego, Izby Cywilnej, Pracy i Ubezpieczeń Społecznych” 1987, nr 7, poz. 95; Legalis.

Uchwała SN z 22 maja 2009 roku, III CZP 21/09, „Orzecznictwo Sądu Najwyższego. Izba Cywilna" 2010, nr 1, poz. 13.

Uchwała SN z 9 grudnia 2011 roku, III CZP 79/11, „Orzecznictwo Sądu Najwyższego. Izba Cywilna" 2010, nr 2012, nr 6, poz. 74 .

Wyrok SN z 21 czerwca 1965 roku, III PR 18/65; „Nowe Prawo” 1966, nr 4; Legalis.

Wyrok SN z 17 grudnia 1966 roku, I CR 447/66; „Orzecznictwo Sądu Najwyższego, Izby Cywilnej, Pracy i Ubezpieczeń Społecznych” 1967, nr 9, poz. 153; Legalis.

Wyrok SN z 8 stycznia 1968 roku, II CR 300/67; Legalis.

Wyrok SN z 22 listopada 1972 roku, III CRN 2/72; Legalis.

Wyrok SN z 12 grudnia 1973 roku, II CR 668/73, Legalis.

Wyrok SN z 15 września 1977 roku, II CR 297/77; „Orzecznictwo Sądu Najwyższego, Izby Cywilnej, Pracy i Ubezpieczeń Społecznych” 1978, nr 7, poz. 114; Legalis.

Wyrok SN z 18 maja 1979 roku, III CRN 287/78; „Orzecznictwo Sądu Najwyższego, Izby Cywilnej, Pracy i Ubezpieczeń Społecznych” 1980, nr 1, poz. 8; Legalis.

Wyrok SN z 22 sierpnia 1979 roku, I PRN 102/79, „Orzecznictwo Sądu Najwyższego, Izby Cywilnej, Pracy i Ubezpieczeń Społecznych" 1980, nr 3, poz. 53; Legalis.

Wyrok SN z 30 października 1979 roku, II CR 355/79; „Orzecznictwo Sądu Najwyższego, Izby Cywilnej, Pracy i Ubezpieczeń Społecznych” 1980, nr 4, poz. 75; Legalis.

Wyrok SN z 15 maja 1980 roku, II CR 110/80; OSNC 1980/11/222; Legalis.

Wyrok SN z 26 maja 1983 roku, II CR 32/83, „Nowe Prawo” 1985, nr 2, s. 116; Legalis.

Wyrok SN z 28 sierpnia 1986 roku, I CR 320/86; Legalis.

Wyrok SN z 15 września 1986 roku, III CRN 198/86; Legalis.

Wyrok SN z 25 maja 1988 roku, II CR 129/88; Legalis.

Wyrok SN z 12 października 2001 roku, V CKN 631/00, „Orzecznictwo Sądu Najwyższego. Izba Cywilna" 2002, nr 7-8, poz. 91. 